\title{
Special feature in honor of Shin-Kun Peng
}

\author{
Fu-Chuan Lai ${ }^{1}$
}

Published online: 15 October 2019

( ) The Japan Section of the Regional Science Association International 2019

Professor Shin-Kun Peng has served in the Institute of Economics of the Academia Sinica for 37 years, since 1982. He has served as the Director of the Institute for 6 years and is currently a Distinguished Research Fellow and Secretary General of the Academia Sinica. Professor Peng has made valuable academic contributions for decades in the fields of international trade, regional economics and industrial organization. His research scope mainly includes: (1) exploring the impact of international trade, regional integration and transnational labor migration on the economy and social welfare for different countries. His research topics are related to the impacts of globalization on migration, foreign investment, outsourcing manufacturing, patent licensing, mergers and acquisitions, income distribution, unemployment and environmental pollution; (2) exploring some regional economic issues, like land, housing, and the optimal allocation of real estate-related tax systems from the aspect of "New Economic Geography" (NEG); (3) exploring issues related to industrial organization such as competition between manufacturers in their location choices, for instance, the location patterns of chain stores and reasons for the emergence of chain stores. In addition, he also explores the characteristics of product quality differentiation and product category optimization in competition among multiple-product manufacturers.

For the study of related issues such as international trade, regional economics and industrial organization, Professor Peng's research primarily uses the general equilibrium approach. For the discussion and analysis of each topic, not only the decision makers are considered, but also consumers and manufacturers, and some topics even involve the best choices of the government and other participants. In market analysis, this approach considers not only the domestic final product market, but also the factor market, the intermediate financial market, the capital market, the labor market, government revenues and expenditures, and even various types of markets across countries, and the overall welfare maximization of each country. Research conclusions obtained by the general equilibrium approach for the comprehensive exploration of the relevant affected individuals are relatively robust, and also have high recognition in the academic literature.

\section{Fu-Chuan Lai}

uiuclai@gate.sinica.edu.tw

1 Academia Sinica, Taipei, Taiwan 
Professor Peng's research results have been published in the American Economic Journal: Economic Policy, Journal of Economic Theory, Economic Theory, Canadian Journal of Economics, Journal of Economic Dynamics and Control, Regional Science and Urban Economics, in Kan et al. (2017); Berliant et al. (2002), (2014); Peng and Wang (2005); Peng et al. (2006); Chen et al. (2009) and Mai et al. (2008), respectively, and many other high-quality international journals.

Professor Peng is passionate about academic research and actively participates in activities organized by many international economic associations. Moreover, in 2008, he co-organized a conference among four major academic institutions in East Asia, namely the Economics Department of Kyoto University, Seoul National University, the National University of Singapore, and the Institute of Economics, Academia Sinica. This conference has now become an important annual event in East Asia. In addition to academic research, Prof. Peng has proposed countermeasures for real economic problems for the government's reference.

In recognition of Professor Peng's academic achievements, AJRS is publishing a special issue, and I am honored to be responsible for editing this special issue. After a rigorous review, we have accepted a total of eight related papers covering the areas of spatial analyses (Chen, Tsai, and Yao), industrial organization (Cheng and Kao), and regional studies (Okamoto, Otsuka, Pradhan and Narayanan, and Tokunaga) in which Professor Peng specializes.

In this special issue, there are four theoretical papers: Chen (2019) explores the influences of capital mobility on the agglomerative tendency of footloose entrepreneurs in an NEG framework, and finds that the mobility of physical capital plays a stabilizing role in the catastrophic agglomeration caused by footloose entrepreneurs. Yao (2019) analyzes the strategic choice of a spatial price policy between mill pricing and uniform delivered pricing under transportation asymmetry. He finds that when the asymmetry is not too large, mill pricing is a dominant strategy, while when the asymmetry is sufficiently large, mill pricing is no longer a dominant strategy. Cheng and Kao (2019) explores what determines the operational objective of firms involved in quality competition, and finds that both firms will choose to maximize their revenues (profits) and to provide products with identical (different) quality when heterogeneity of consumers' desire for quality is high (low), while both firms choose different objectives and produce different product quality levels when the desire is moderate. Tsai (2019) studies the spatial tax competition in three regions with or without a median location in an NEG model. He finds that the Nash tax rate of the median region will be smaller than that of non-median regions due to the locational advantages of the median location.

The remaining four papers are empirical studies: Okamoto (2019) uses an input-output model to explore the characteristics of urbanization in China and finds that "spatial urbanization" will lead to economic growth by boosting the manufacturing sector, while "institutional urbanization" will cause a structural change towards a service-based economy and avoid the "middle-income trap". Otsuka (2019) explores the price elasticity of residential electricity demand during 1990-2015, which includes an unexpected natural disaster (the great earthquake in eastern Japan in 2011). He finds that households tended to consume electricity according to past patterns, and after the natural disaster, people indeed changed their 
behavior in electricity consumption. It is shown that people are more sensitive to price rises than price falls. Tokunaga (2019) investigates the production locations of final and intermediate goods for Japanese multinational firms in electronics and automotive industries, and finds that the overseas production sites of Japanese multinational firms for their final and intermediate goods are concentrated in the same regions, and the number of production sites for intermediate goods is larger than that of the final goods in East Asia. Pradhan and Narayanan (2019) analyze the intensity of labor migration and its determinants in semi-arid Indian villages. They find that the intensity is affected by family size, dependency ratio, age of the head of the household, ownership of the land and livestock, and the share of remittance in the household's total income.

\section{References}

Berliant M, Peng S-K, Wang P (2002) Production externalities and urban configuration. J Econ Theory 104(2):275-303

Berliant M, Peng S-K, Wang P (2014) Taxing pollution: agglomeration and welfare consequences. Econ Theory 55(3):665-704

Chen C-M (2019) The effect of capital flow on the agglomeration evolution of footloose entrepreneurs. Asia-Pac J Reg Sci. https://doi.org/10.2139/ssrn.1942860

Chen B-L, Peng S-K, Wang P (2009) Intergenerational human capital evolution, local public good preferences, and stratification. J Econ Dyn Control 33(3):745-757

Cheng Y-L, Kao H-H (2019) Product quality and endogenous firm objectives. Asia-Pac J Reg Sci. https:// doi.org/10.1007/s41685-019-00122-X

Kan K, Peng S-K, Wang P (2017) Understanding consumption behavior: evidence from consumers' reaction to shopping vouchers. Am Econ J Econ Policy 9(1):137-153

Mai C-C, Peng S-K, Tabuchi T (2008) Economic geography with tariff competition. Reg Sci Urban Econ 38(1):478-486

Okamoto N (2019) Spatial and institutional urbanisation in China. Asia-Pac J Reg Sci. https://doi. org/10.1007/s41685-019-00113-y

Otsuka A (2019) Natural disasters and electricity consumption behavior: a case study of the 2011 Great East Japan Earthquake. Asia-Pac J Reg Sci. https://doi.org/10.1007/s41685-019-00129-4

Peng S-K, Wang P (2005) Sorting by foot: 'travel-for' local public good and equilibrium stratification. Can J Econ 38(4):1224-1252

Peng S-K, Thisse J-F, Wang P (2006) Economic integration and agglomeration in a middle product economy. J Econ Theory 131(1):1-25

Pradhan K, Narayanan K (2019) Intensity of labour migration and its determinants: insights from Indian semi-arid villages. Asia-Pac J Reg Sci. https://doi.org/10.1007/s41685-019-00133-8

Tokunaga S (2019) Global supply chain, vertical agglomeration and location of final and intermediate goods production sites for Japanese MNFs in East Asia: evidence from the Japanese electronics and automotive industries. Asia-Pac J Reg Sci. https://doi.org/10.1007/s41685-019-00132-9

Tsai J-F (2019) Tax competition with spillover public goods in a median location model. Asia-Pac J Reg Sci

Yao J-T (2019) The impact of transportation asymmetry on the choice of a spatial price policy. Asia-Pac J Reg Sci. https://doi.org/10.1007/s41685-019-00110-1

Publisher's Note Springer Nature remains neutral with regard to jurisdictional claims in published maps and institutional affiliations. 